\title{
Foreign Relation of Nepal with China and India
}

\section{Girdhari Dahal}

\begin{abstract}
Nepal is sandwiched between two giant economic and politically powerful nations - China and India. Due to its geographical proximity and historically long multi-faceted linkages to China and India, Nepal's foreign policy with China and India is not distinctly independent but is mutually interdependent. Nepal's foreign policy has always prioritized maintaining balanced relation with these two nations for safeguarding its national interests, integrity and independence. In practice, Nepal has observed friendly and cordial relation with China while the relation with India has been both friendly and hostile. Nepal is firmly committed to 'One China Policy' and had just signed OBOR (One Belt One Road) and respects India's national independence and integrity. China has shown respect to Nepal's sovereignty and has not interfered in Nepal's internal issues while India has been seen trying to influence Nepal's internal politics. The main objective of this paper is to explore the foreign relation of Nepal with, China and India. This paper makes a brief description and analysis of Nepal's foreign policy, political and economic dynamics of these relations, and new developments in Nepal-China and Nepal-India relation based on secondary sources. Election of federal, provincial and local level was held after the declaration of new constitution. Nepal's new priority in foreign relation should be economic prosperity. So, Nepal, China and India must reach a new consensus to re-build strong
\end{abstract}


economic ties for mutual benefit of all.

Keywords: Affair, landlocked, non-alignment, diplomatic relation

\section{Introduction}

Nepal is a landlocked country. It is located between two giant economic nations China and India. The northern border of Nepal, which is mostly mountainous, is connected with China while southern (which is mostly plain), eastern and western border of Nepal is connected with India. The Constitution of Nepal (2015) has outlined the directive principles, policies and obligations of the State regarding its foreign policy. The foreign policy of Nepal is guided by the abiding faith in the United Nations and policy of non-alignment, mutual respect for each other's territorial integrity and sovereignty, non-interference in each other's internal affairs, respect for mutual equality, non-aggression and the peaceful settlement of disputes, and cooperation for mutual benefit as per the guiding principles of our foreign policy (Shrestha, 2018). Although Nepal established a diplomatic relation with India and China respectively in 13th June, 1947 and 1st August 1955 (MOFA, 2017), Nepal has a relation with China and India since their existence. Nepal's foreign relations with China and India have evolved through different events, stages and periods in history. So, Nepal has multitude of relations with these two neighboring nations- ranging from social, cultural, religious, geo-political, and economic to diplomatic relations. These relations have grown through different ups and downs, and transformed from simple, linear relation to complex, weired relations. At present, Nepal has established diplomatic relations with 155 nations (MOFA, 2017) but Nepal's foreign relations with China and India are much broader, wider, vital, and dynamic and feature special characteristics. After the declaration of new constitution and establishment of federalism in Nepal, Nepal's 
relation with China and India needs to be redefined and revised in the changed perspective and is sure to evolve from new dimension. The geographical location, size, natural resources, population and other physical features and environmental features influence a country and determine the political, military level of economic development and cultural characteristics of a nation (Bhattarai, 2005). So, at this scenario, it is worthwhile to discuss historical development of Nepal's foreign relation with China and India; different bilateral treaties with these nations; dynamics of these relations in Nepal's geo-politics, socioeconomy, and culture; and different issues related to this.

\section{Objectives and Methodology}

The general objective of this paper is to explore the foreign relation of Nepal with China and India. This paper makes a brief analysis of Nepal's foreign policy with China and India, political and economic dynamics of these relations and new developments in Nepal-China and Nepal-India relation based on secondary data.

\section{Review of Literature}

Constitutionally, foreign policy is to be guided by the principles of the United Nations Charter, non-alignment, Panchsheel (five principles of peaceful coexistence), international law and the value of world peace (Constitution of Nepal, 2015). In practice, Nepal's foreign policy has not been directed towards projecting influence internationally but towards preserving autonomy and addressing domestic economic and security issues.

Nepal's foreign relations in consonance with the policies and guidelines of Government of Nepal are made to protect Nepal's independence, sovereignty, territorial integrity, and enhance national interest abroad; to promote bilateral, regional and 
multilateral relations for the socio-economic development of the country, to promote friendly relations with all the countries of the world and particularly with its immediate neighbors, on the basis of sovereign equality, mutual respect, trust, goodwill and understanding to play an active role in the United Nations and other international organizations, in order to promote international peace, security and development to play a positive and meaningful role in the world (MOFA (2017). Because of its geographical proximity to and historical links with China and India, Nepal's foreign policy was focused mainly on maintaining close and friendly relations with these two countries and on safeguarding its national security and independence (Savada, 1991). The successful second pro-democracy movement, the country needs to examine its conduct of foreign policy in the context of those changes and formulate and adopt its foreign policy correspondingly (Bhattarai, 2013). With respect to all of its neighbors, Nepal has taken concrete steps over the past two years to promote goodwill and deep economic and social connectivity with India. But nationalist sentiments in all these countries often directed against India as the region's predominant power - will continue to present a challenge (Jaishankar, 2016). Nepal needs entering into treaties and agreements on the basis of equality and mutual interest, by reviewing past treaties.

\section{Nepal-China Relation}

Nepal and China share deep rooted and age old friendly relations with each other. The marriage of Nepalese Princess Bhrikuti Devi with the emperor of Tibet, Songtsan Gampo in 7th century (Chinese Buddhist Enclopedia), visit of Nepali craftsman Araniko to China in the 13th century and visits to Nepal by Chinese monks and scholars at different periods in history paved a solid foundation in the development of Nepal-China relation 
(Bhandari, 2017).

Nepal and China officially established diplomatic relation in 1955. At present, Nepal and China enjoys friendly and cordial relation by respecting each other's sovereignty, territorial integrity and independence. The Chinese Embassy to Nepal (2007) has characterized Nepal-China relations as based on "trust, equality and sincerity". It further adds;

The two countries never threat each other, harm each other or doubt each other; but always respect each other, believe each other and help each other. The Chinese Government and people firmly pursue the principle that a country is equal with others no matter how big or small it is. In the past 50 years, abiding by the Five Principles of Peaceful Coexistence, through equal dialogue, communication and coordination, China and Nepal have made excellent cooperation and achieved great accomplishments in bilateral political relations, regional affairs and international forums... China treats Nepal as its closest neighbor and best friend. We highly appreciate the strong support Nepal has given to us over the years on the questions of Taiwan and Tibet and other major issues related to China's sovereign rights and interests. (Chinese Embassy to Nepal, 2015)

Nepal has always shown strong commitment to 'One China Policy' and has never allowed its soil to be used for any hostile activities against China. China has also supported late king Birendra's proposal to declare Nepal as 'Peace Zone' and has never interfered with the internal affairs of Nepal and highly respected the road of development chosen by the Nepalese people (Chinese Embassy, 2007). China has been the good partner in Nepal's development endeavor. In this way, Nepal and China are enjoying good relations with each other. 


\section{Nepal-India Relation}

Nepal and India also share age-old and deep rooted relations with each other. Unlike China, there are more ups and downs in Nepal-India relations. Despite this bitter truth, Nepal-India relation is multi-faceted and it is basically characterized by an open border and a strong contact between people to people. In the past, Nepal and India had shared a very glorious and friendly relation which was basically founded on culture, religion and trade. Marriage of Nepalese Princess Sita with the prince of Ayodhya, Ram visit of Char Dham in India by Nepali Hindu pilgrimage; visit to Pashupatinath and Muktinath by Indian Hindu pilgrimage, and cross border marriage between Nepali and Indian nationals from ancient time till date are the history building blocks of Nepal-India relations.

Nepal and India officially established diplomatic relation in 1947. At present, Nepal-India relation is largely directed by 1950 India-Nepal Treaty of Peace and Friendship, which Nepalese side considers as unequal. India has greater- and unnatural- influence in Nepal's internal politics which is not liked by the Nepalese nationals. Although Nepal and India have reached the consensus to revise all the previous unfair treaties-especially 1950 IndiaNepal Treaty of Peace and Friendship, they are not finalized yet. There exists two contrasting relationship between Nepal and India. People to people relation are always good and stable while the government to government relation has many ups and down and is very volatile. There are some border disputes between Nepal and India which also make situation tense in the border area very often. Despite all these facts, Nepal is in the position to maintain good relation with India respecting each other's sovereignty, integrity and independence.

India's mindset towards Nepal can best be understood by 
the statements of Indian Embassy to Nepal (2015) on new constitution, promulgated by taking the support of more than two third majority of constituent assembly members, as:

Nepal's second Constituent Assembly promulgated a Constitution on 20 September 2015 amid protests by Madhes-based parties and other groups. The Government of India has expressed grave concern regarding the ongoing protests and has urged the Government of Nepal to make efforts to resolve all issues through a credible political dialogue.

This statement implies that India has their own concern and interests on Nepal's domestic issues. Nowadays the government Nepal and Indian have started to make intellectual response to review the 1950 treaties. After the application of new constitution in Nepal, situation has changed and left alliance has formed the government from the centre to the most local levels in Nepal government of Nepal. In this way, Nepal and India have both friendly and hostile relations between them.

\section{Result of China-Nepal Discussion}

\section{Assistance to Develop Nepal}

China has remained as one of the major donor countries for Nepal. Nepal and China first signed an agreement on economic aid in 1956. China has been providing financial and technical assistance to Nepal in the areas of infrastructure development, transportation, industrial development, health, education, hydro power development and so on. Some of the major projects built under Chinese assistance are: Arniko Highway, Prithvi Highway, Kathmandu Ring Road, Pokhara-Baglung Road, Syaphrubesi Rasuwagadhi Road Project, Bansbari Leather and Shoes Factory, Hetauda Cotton Textile Mills, Harisidhi Brick Factory, Bhrikuti 
Paper Mills, Lumbini Sugar Mills, Sunkoshi Hydroelectricity Plant, Pokhara Water Conservancy and Irrigation Project (Multipurpose), B.P. Koirala Memorial Cancer Hospital, Civil Service Hospital, National Ayurveda Research Centre Sports, Satdobato Sports Complex, City Hall in Kathmandu and Birendra International Convention Centre (MOF, 2014). Also, the ongoing projects under Chinese assistance include: Upper Trishuli Hydropower Project, Kathmandu Ring Road Improvement Project, Pokhara International Regional Airport, and National Armed Police Force Academy Project (MOF, 2014). With the signing of the Memorandum of Understanding on Cooperation under the one Belt and one Road Initiative on 12 May 2017 in Kathmandu between Nepal and China, new avenues for bilateral cooperation in the mutually agreed areas are expected to open (MOFA, 2017).

\section{Trade and Investment}

China is the second largest trading partner of Nepal. In 2015/16, total exports to China stood at US\$181 million with marginal increase from US\$179 million in the previous fiscal year. In contrast, import from China has been growing at the rate of 39 per cent per year. It rose from US\$421 million in fiscal year $2009 / 10$ to US $\$ 1,247$ million in fiscal year 2015/16. Although China has given zero tariff entry facility to over 8000 Nepali products that starts from 2009, Nepal exports only 370 products including noodles and agro products to China (MOFA, 2017).

China is the largest source of Foreign Direct Investment in Nepal. Chinese investors have shown intent to spend over $\$ 13.51$ billion in Nepal during the Nepal Investment Summit concluded in Kathmandu in March 2017 (The Kathamandu Post, 2017). 


\section{Tourism}

It will be the major boost to Nepal tourism sector of 150,000 Chinese tourists, by air visit Nepal in 2018 as expected, according to NTB. Nepal received a total of 104,664 Chinese tourists in 2017, according to Nepal's Department of Immigration. China is the second largest source of foreign tourist to Nepal. Over 1 lakh Chinese tourists visit Nepal annually. China has designated Nepal as the first tourist destination in South Asia for its people. The Government of Nepal has waived visa fees for the Chinese tourist effective from 1 January 2016 (Xinhua net, 2018).

\section{Recent Development in Nepal-China Relation}

One of the landmarks in Nepal-China relation was built when the then Prime Minister K.P. Oli signed Transit and Transport Agreement in his official visit to China in 2016. At present, Nepal and China are enjoying very friendly, broader and deeper relation followed by frequent exchange of high level officials' visit from both sides. Nepal and China have new tangent treaties for alternative point of view as well as one belt and one road initiative. In the recent years, the leaders of India and China have focused on development and economic prosperity. They have made significant advancement in road, railway and nautical connectivity. Xi Jinping's ambitious project of one belt one road has the aim to be connected with about 60 countries of Asia, Africa and Europe. President Xi Jinping has a vision of creating a 'community of common destiny' through 'Go West' and 'Peripheral Strategy'(Subedi, 2016) Nepal has also supported and agreed with this ambitious one belt one road project.

\section{India}

\section{Development Aids}

Nepal and India officially started economic cooperation in Foreign Relation... Girdhari Dahal - 54 - 
1951(MOF, 2014). India is providing broad spectrum financial and technical assistance in many projects in the past and at present. Some of the projects completed under Indian assistance are: Nepal's first six airports at Gauchar (1951), Simra, Janakpur, Bhairahawa, Pokhara and Biratnagar, Koshi Barrage, Devighat Hydropower and Irrigation Project, Janakpur-Jayanagar Railway's East -West Highway, B. P. Koirala Institute of Health Sciences, National Trauma Centre (MOF,2014). Currently, 36 intermediate and large projects such as construction of a National Police Academy at Panauti, Nepal Bharat Maitri Pashupati Dharmashala at Tilganga, and a Polytechnic at Hetauda are at various stages of implementation.

\section{Trade and Investment}

India is Nepal's largest trade partner and the largest source of foreign investments, besides providing transit for almost entire third country trade of Nepal. India accounts for over two-third of Nepal's merchandise trade, about one-third of trade in services, $36 \%$ of foreign direct investments, almost $100 \%$ of petroleum supplies (Indian Embassy to Nepal, 2017). Nepal has huge trade deficit with India and it is growing every year.

Indian firms are the biggest investors in Nepal, accounting for about $38.3 \%$ of Nepal's total approved foreign direct investments. There are about 150 operating Indian ventures in Nepal engaged in manufacturing services, banking, insurance, dry port, education and telecom, power sector and tourism industries.

\section{Education}

Indian government is providing around 3000 scholarships/seats annually to Nepali nationals for various courses at the $\mathrm{Ph} \mathrm{D}$, master, bachelor and plus-two levels in India and in Nepal. 


\section{Indian Community in Nepal}

Around 6, 00,000 Indian national have been living in Nepal and around 10,00,000 Nepalese nationals have been working in different parts of India (Nepal India relation, 2017). Nepal and India have got open border. There is a people to people relation among the Indian and Nepalese people whether it is in the east or west brooder area.

\section{Recent Development in Nepal-India Relation}

There were ups and downs in Nepal-India relation in the past. At present also, Nepal and India have very volatile and unstable relation -sometime friendly and sometime hostile, although Nepal always wants to have stable relation with India. There has been lack of confidence and mutual trust to one another in NepalIndia relation after declaration of new constitution in 2015 that followed unannounced trade embargo from Indian side. Nepalese nationals' sentiment towards India is not good thereafter and people think that India has its own interests in Nepal's internal issues. So, in order to build good relation between Nepal and India, Indian government should respect Nepal's sovereignty and independence and all business dealings must be based on equal status. Indian government is directly and indirectly supporting to Madhes-based parties. Indian government through imposing undeclared blockage has violated Nepal's trade and transit right. Such influences could not promote good relation among adjacent neighbors. In Nepal India border, we can find many examples of marriage among Indian and Nepali people. India has reoriented its foreign policy to boost bilateral ties with Nepal, especially after Narendra Modi came to power in 2014. Another reason for the Modi government to engage Kathmandu at the highest political level is China's increasing investment in infrastructure, energy and other sectors of Nepal. 
The Federal Democratic Republic of Nepal has traditionally maintained a non-aligned policy and enjoys friendly relations with neighboring countries. As a small, landlocked country wedged between two larger and far stronger powers, Nepal maintains good relations with both countries the People's Republic of China and India. Since the establishment of diplomatic relations between Nepal and China, the rivalry between India and China has been increasing on Nepalese soil. India wants to uphold its traditional leverage in Nepal; whereas China wants to puncture this relationship and seeks its own space in different layers of administration, security agencies, army and not the least among the people (Jha, 2010). Nepal remains poor and deprived in $21 \mathrm{st}$ century while India has acquired a central place in the world with a very high development rate (Kavitha, 2016).

The India-Nepal Treaty of Peace and Friendship of 1950 forms the bedrock of the special relations that exist between India and Nepal. At that time there was autocratic Rana regime and close society in Nepal. People had started getting organized against the Rana rulers and the Rana rulers too were just thinking how to prolong their rule. The treaty signed in such a context is not suitable for present democratic situations. Under the provisions of this Treaty, the Nepalese citizens have enjoyed unparalleled advantages in India, which avalled facilities and opportunities at par with the Indian citizens. The Treaty has allowed Nepal to overcome the disadvantages of being a land-locked country. Beginning with the 12-Point Understanding reached between the Seven Party Alliance (SPA) and the Maoists at Delhi in November 2005, the Government of India welcomed the roadmap laid down by the historic Comprehensive Peace Agreement of November 2006 towards political stabilization in Nepal through peaceful reconciliation and inclusive democratic processes. 
Nepal and India are so well bounded by various social, economic, geographical, cultural, and religion ties (Saran, 2017). Basically, Anti India sentiment is growing in Nepal especially after Indian blockade of 2015. Treaties concluded between the two countries in different times have always remained debatable. By realizing the fact, a joint mechanism with a group of foreign policy expert called Eminent Persons Group (EPG) has started reviewing all the treaties previously signed between Nepal and India (The Kathmandu Post, 6 July, 2016;1)

\section{Conclusion}

Nepal has age old and deep rooted relations between both China and India. Nepal-China and Nepal-India relations have evolved through different circumstances, stages and periods till date. Nepal-China and Nepal-India relations have multitude linkages- ranging from social, cultural, religious, geo-political, and economic to diplomatic affairs. One belt one road is the milestone point for both Nepal and China of 21st century. There is more mutual trust and less - or no disagreement-in NepalChina relations but there are less mutual trust and more disputes in Nepal-India relation. The greatest challenges in Nepal's foreign relations, at the present context, are: to build good mutual trust and win confidence Indian from in Nepal-India relations, to maintain balanced and equal distance in relations with China and India, to make China and India join hands together for broader, deeper and stronger economic ties for equal mutual benefits of all. After the declaration of new constitution and new election being held under it, China and India must be ready in re-structuring foreign affairs with Nepal in the changed perspective from newer dimension. Also, economic growth, development and prosperity must take central stage while redefining and revising the oneto-one and triangular relation between Nepal, China and India, 
keeping respect for each other's national sovereignty, integrity and independence intact. In conclusion, Nepal's foreign relation with China and India must be directed towards regional peace, integrity and prosperity.

\section{References}

Bhandari, Bibek (2017). China's Cultural debt to Nepalese artist in the $13^{\text {th }}$ century court of Kubal Khan. http://www.scmp. com/magazines/post-magazine/long-reads/article/2122813/ chinas-cultural-debt-nepalese-artist-13th-century

Bhattari, Rajan (2005). Geopolitical specialties of Nepal and international approach to conflict transformation, Nepal: Friends for Peace in Jan 2005. https://indiamadhesi.files. wordpress.com/2008/10/geopolitics-of-nepal.pdf

Bhattari, Rajan (2013). Foreign Policy in Nepal, Kathamandu: Maratin Chautari, http://nepalpolicynet.com/images/stories/ happenings/130526_Invitation_Policy\%20Discussion Copy.pdf

Chinese Buddhist Encyclopedia.

Dahal, G. (2015). Constitutional Assembly of Nepal Milestone for Peace, Development and Political Stability: KMC Journal of Interdisciplinary Studies, Vol.4.1, p.70-77.

Embassy of Nepal WashingtonDC,http://www.nepalembassyusa. org/guiding-principles/

Embassy of Nepal (2015). http://www.nepalembassy.org/ guiding-principles/

Government of Nepal Ministry of Foreign Affairs MOFA http:// mofa.gov.np/foreign-policy/diplomatic-relations/

Government of Nepal Ministry of Foreign Affairs MOFA http:// mofa.gov.np/foreign-policy/foreign-policy/ 
Indian Embassy to Nepal (2015). http://np.india-embassy.org. http://countrystudies.us/nepal/64.htm http://mof.gov.np/ieccd/newsbook/20140820115245.pdf http://mofa.gov.np/foreign-policy/diplomatic-relations/ http://mofa.gov.np/foreign-policy/foreign-policy/ http://mofa.gov.np/nepal-china-relations/ http://np.china-embassy.org/eng/ChinaNepal/t362330.htm http://www.mea.gov.in/Portal/ForeignRelation/8_Nepal_ November_2017.pdf http://www.mea.gov.in/Uploads/PublicationDocs/191_ panchsheel.pdf

https://archive.org/stream/nepalbhutancountsava/ nepalbhutancountsava_djvu.txt

https://www.indianembassy.org.np/pdf

https://www.mea.gov.in/Images/pdf

https://www.mea.gov.in/Portal/ForeignRelation/Nepal_ July_2014_.pdf

https://www.mea.gov.in/Portal/ForeignRelation/Nepal_ July_2014_.pdf

India-foreign-relation-2012.pdf

Jaishankar, Dhruva (2016). India's Five Foreign Policy Goals: Great Strides, Steep Challenges, https://www.brookings. edu/opinions/indias-five-foreign-policy-goals-great-stridessteep-challenges/

Jha, Hari Bansh (2010). Nepal's Border Relations with India and China http://src-h.slav.hokudai.ac.jp/publictn/eurasia border_review/Vol41/V4N104J.pdf 
Kavitha K K, (2016). The Changing Paradigm of India- Nepal

Relations: Problems and http://www.questjournals.org/ jrbm/papers/vol4-issue5/B451015.pdf

Saran, Shyam (2017). How India Sees the World. New Delhi: Juggernaut Books.

Savada, Andrea Matles (1991). Nepal and Bhutan: Country Studies,

Shivakoti, Gopal (2013). Dictionary of Politics Nepali-EnglishNepali, Kathamandu: Pairavi Prakashan.

Shrestha, Rajendra B. (2018, 1 Janaury). Foreign Policy Challenges and Opportunities, Kathamandu : The Rising Nepal.

Subedi, Suryaprasad (2016). Kathamandu, Kantipur Publication. The Kathamandu Post (2017, 4 March). Kathamandu, Kantipur Publication.

The Kathmandu Post (2016, 6 July). Kathamandu, Kantipur Publication.

Xinhuanet (2018). Chinese tourists flock to Nepal during Chinese New Year http://www.xinhuanet.com/english/201802/18/c 136983861.htm. 